\title{
Pneumonia masivă şi pancitopenia conduc la diagnosticul de leucemie acută limfoblastică la copil - prezentare de caz şi date din literatură
}

\author{
Lorena Elena Meliț,2, Cristina Oana Mărginean ${ }^{1,2}$, Mihaela Ioana Chinceşan ${ }^{1,2}$, \\ Iulia Armean', Vlăduț Ştefănuț Săsăran², Maria Oana Mărginean² \\ ${ }^{1}$ Clinica Pediatrie I, Spitalul Clinic Judeţean de Urgenţă Târgu Mureş, România \\ ${ }^{2}$ Universitatea de Medicină şi Farmacie, Târgu Mureş, România
}

\begin{abstract}
REZUMAT
Leucemia acută limfoblastică ( $L A L)$ reprezintă unul dintre cele mai comune tipuri de neoplazii la copii, dar, în acelaşi timp, unul dintre cancerele cu cel mai bun prognostic. Pancitopenia tranzitorie a fost descrisă ca fiind o entitate foarte rară, definită ca o stare preleucemică la copii şi adolescenţi. Prezentăm cazul unui copil în vârstă de 2 ani, de sex masculin, cu infecţie a tractului respirator de 2 săptămâni, fără ameliorare după antibioterapie, internat în clinica noastră cu febră, stare generală influenţată, tuse productivă, paloare marcată, edeme palpebrale şi abces perianal. Analizele de laborator au evidenţiat anemie severă, leucopenie uşoară şi markeri inflamatori crescuţi. Radiografia toracică a pus în evidenţă o pneumonie masivă dreaptă. Copilul a fost externat după 3 săptămâni de antibioterapie cu spectru larg, prezentând evoluţie favorabilă. Hemoleucograma de control după aproximativ 2 săptămâni de la externare a arătat leucocitoză marcată, iar imunofenotiparea măduvei osoase a stabilit diagnosticul de leucemie acută limfoblastică cu celule pre-B. Toţi pacienţii care au primit tratament pentru pancitopenie trebuie monitorizaţi adecvat în pe termen lung pentru a exclude dezvoltarea ulterioară a unei potenţiale LAL.
\end{abstract}

Cuvinte cheie: pneumonie, copil, leucemie acută limfoblastică, pancitopenie

\begin{abstract}
Abrevieri
LAL: leucemie acută limfoblastică

LAM: leucemie acută mieloblastică

SC: suprafață corporală

HLG: hemoleucogramă

PCR: proteina $\mathrm{C}$ reactivă

VSH: viteza de sedimentare a hematiilor

Î: înălțime
\end{abstract}

\author{
Hb: hemoglobină \\ Htc: hematocrit \\ Leu: leucocite \\ ITRI: infecție a tractului respirator inferior \\ VCM: volum celular mediu \\ Pre-LAL: faza preleucemică \\ G: greutate
}

\section{INTRODUCERE}

Infecțiile de tract respirator, care pot afecta tractul respirator superior sau inferior, sunt probabil cele mai frecvente tipuri de infecții raportate la ființa umană (1). Infecțiile de tract respirator inferior (ITRI) reprezintă un grup de boli care cuprind, printre altele, pneumonia, şi pot fi unele dintre cele mai frecvente cauze de morbiditate şi mortalitate în întreaga lume, mai ales la vârsta pediatrică. De cele mai multe ori, ITRI sunt forme uşoare, tranzitorii, şi în anumite cazuri autolimitante, astfel că mulți pacienți afectați de aceste patologii tind să le neglijeze (2). Astfel, în anumite condiții, fără un tratament adecvat, ele pot duce la boli severe, potențial fatale. ITRI sunt foarte frecvente la copii, fiind, probabil, cel mai frecvent tip de infecție care apare după naştere, iar pneumonia este cel mai adesea ultima patologie care apare înainte de deces (3). În multe cazuri, agenți etiologici ai ITRI nu pot fi identificați şi ei depind de zona geografică (4). În plus, etiologia şi simptomatologia pot varia, de ase- 
menea, în funcție de alți factori, cum ar fi: vârsta, genul, sezonul, tipul de populație cu risc crescut etc. (1).

Leucemia este o formă relativ rară de neoplazie care apare când celulele stem nu se maturează adecvat ducând la producția lor în exces (4). Deşi leucemia reprezintă aproximativ doar 3\% dintre neoplaziile adultului, ea este una dintre cele mai frecvent întâlnite tipuri de cancer la copii, reprezentând aproximativ $15 \%$ dintre cancere diagnosticate sub vârsta de 15 ani $(5,6)$. În funcție de tipul ce celulă stem afectată, leucemiile acute sunt împărțite în două categorii principale: leucemia acută limfoblastică (LAL) și leucemia acută mieloblastică (LAM). În LAL este afectată dezvoltarea celulei stem limfoide, ajungând doar la primul stadiu de maturare. Astfel, celulele stem limfoide se pot dezvolta în limfoblaşi sau, cel mult, în limfocite B sau T cu funcție deficitară, care nu sunt capabile să furnizeze o funcționare normală a sistemului imun. Mai mult, LAL este împărțită, în funcție de tipul liniei celulare afectate, în LAL cu celule $\mathrm{T}$, dacă sunt afectate limfocitele $\mathrm{T}$ (aproximativ 15\% dintre cazuri), sau cu celule B, dacă sunt afectate limfocitele B (restul de $85 \%$ dintre cazuri) (7). Din cauza acumulării în exces a celulelor leucemice anormale în măduva osoasă şi sângele periferic, cele mai frecvente simptome întâlnite la pacienții cu LAL sunt: infecții recurente sau alte simptome flu-like, febră, anemie, sângerare, oboseală (7). Cu toate acestea, anumite studii au demonstrat că pancitopenia tranzitorie poate fi legată de LAL la copii şi adolescenți $(8,9)$. Această fază pancitopenică este rară şi poate apărea în aproximativ $2 \%$ dintre cazurile de LAL la copii, fiind considerată o condiție preleucemică (pre-LAL) (10). Această fază poate dura de la câteva săptămâni la câteva luni, iar remisia sa poate fi spontană sau indusă de corticosteroizi, urmată de transformarea subsecventă în LAL tipică (11). Un protocol de chimioterapie corespunzător şi monitorizarea adecvată pot duce la remisie în aproximativ 95\% dintre cazurile pediatrice diagnosticate cu LAL, iar 80\% dintre cei care ajung în remisie sunt cel mai probabil supraviețuitori pe termen lung (12). Prognosticul pacienților diagnosticați cu ALA este similar după chimioterapie standard, indiferent de prezența sau absența pre-LAL (11).

Prezentăm acest caz de LAL la un copil mic cu scopul de a sublinia importanța unei monitorizări adecvate după o patologie infecțioasă severă, şi pentru a evidenția că prezența unei faze pancitopenice tranzitorii poate masca diagnosticul de LAL fără o urmărire corespunzătoare.

\section{Prezentare de caz}

\section{Motivele internării}

Prezentăm cazul unui copil, de sex masculin, în vârstă de 2 ani, internat în clinica noastră pentru următoarele motive: febră şi tuse seacă de 2 săptămâni, care a devenit productivă de o zi. Antecedentele familiale nu au fost semnificative. Menţionăm, de asemenea, că pacientul nu a prezentat istoric de expunere la toxice (fum de țigară, radiații, medicație, etc.) sau alți factori de risc, nici în timpul vieții intrauterine, nici după naştere. Antecedentele personale au evidențiat un episod de diaree infecțioasă în urmă cu 6 luni, un episod de pneumonie (în urmă cu 2 luni) şi un episod de angină acută pultacee (în urmă cu 1 lună). Debutul simptomatologiei actuale a fost cu 2 săptămâni anterior internării în clinica noastră, cu febră şi tuse uscată, pentru care medicul de familie a recomandat tratament antibiotic şi simptomatic, dar fără ameliorare.

\section{Examen clinic}

Examenul obiectiv la momentul internării a arătat următoarele elemente patologice: stare generală influenţată, edeme palpebrale, abces perianal, tuse productivă, faringe şi amigdale hiperemice, detresă respiratorie, murmur vezicular diminuat pe hemitoracele drept, saturație în $\mathrm{O}_{2} 98 \%$, hepatomegalie (ficat la $2 \mathrm{~cm}$ sub rebordul costal drept), G: $18,5 \mathrm{~kg}$, Î: $95 \mathrm{~cm}, \mathrm{SC}: 0,70 \mathrm{~m}^{2}$.

\section{Evaluare diagostică}

HLG inițială a evidențiat anemie severă (Hb 5,5 g/dL, Htc 18,5\%, VCM 80,8 fL), uşoară leucopenie (Leu 3600/ $\mathrm{LL}$ ), markeri inflamatori crescuți (PCR 15,41 mg/L, VSH $105 \mathrm{~mm} / \mathrm{h})$. Frotiul periferic a arătat predominanța limfocitelor $(88 \%)$, eritrocite hipocrome, microcite, ovaloide, şi limfoplasmocite 2/100 leucocite. Radiografia toracică a pus în evidență o opacitate de intensitate subcostală, la nivelul lobilor superior şi mijlociu drept, stabilind diagnosticul de pneumonie masivă dreaptă (Fig. 1).

Am efectuat, de asemenea, o ecocardiografie, care a fost în relații normale, şi o ecografie abdominală, care a evidenţiat hepatomegalie moderată şi meteorism abdominal. Am solicitat consult chirurgical pentru abcesul perianal, care a recomandat spălături cu antiseptice de 3-4 ori pe zi. Examenul bacteriologic din secreția abcesului a pus în evidență Enterococccus faecium. Toate hemoculturile au fost negative. Am exclus tuberculoza pulmonară pe baza examenului negativ din aspiratul gastric, a prezenței cicatricii postvaccinare BCG şi a intradermoreacției PPD negative, stabilind diagnosticul de pneumonie masivă dreaptă şi anemie severă. 


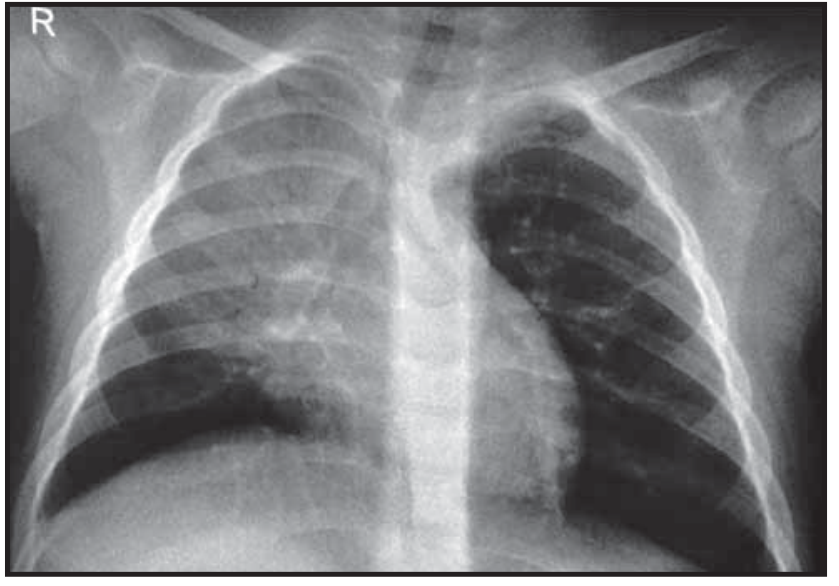

FIGURA 1. Aspect radiologic la internare

\section{Evaluare terapeutică}

Am administrat o asociere de antibiotice cu spectru larg (Meronem + Vancomicină) şi tratament simptomatic, dar, după 7 zile de tratament, pacientul a dezvoltat o tumefactie la nivelul genunchiului drept, asociată cu artralgie şi impotență funcțională. Ecografia articulară a evidențiat colecție lichidiană intraarticulară sugerând o artrită septică. Examenul radiologic de control a arătat atelectazie la nivelul lobului mijlociu drept (Fig. 2).

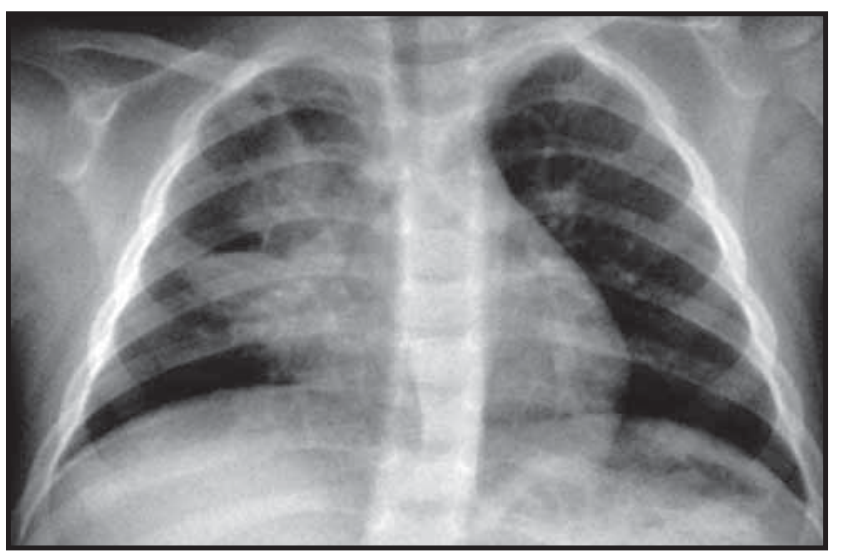

FIGURA 2. Atelectazie a lobului mijlociu drept

Astfel că am efectuat bronhoscopie, care a evidenţiat multiple secreții mucoase, vâscoase în lumenul bronşic. Am luat în considerare o posibilă fibroză chistică, dar testul sudorii a fost negativ. Am continuat tratamentul antibiotic timp de încă 2 săptămâni, externând ulterior pacientul cu o uşoară impotență la nivelul genunchiului drept, fără alte modificări paraclinice.

\section{Monitorizare și evoluție}

Am reevaluat pacientul după 10 zile de la externare, iar evoluţia sa clinică a fost bună, însă parametrii de laborator au arătat leucocitoză marcată (Leu 29.000/ $\mu \mathrm{L}$ ) cu limfocitoză. Frotiul din sângele periferic a evidențiat următoarele: limfoblaşti
$5 \%$, nesegmentate $2 \%$, segmentate $25 \%$, monocite $2 \%$, limfocite $66 \%$, un număr scăzut de trombocite şi un număr absolut de blaşti de 250 . Astfel, am ridicat suspiciunea unei leucemii acute limfoblastice şi am efectuat o biopsie din măduva osoasă, care a arătat un număr crescut de celule în măduvă, infiltrat cu limfoblaşti (74\%), cu un aspect morfologic de $\mathrm{L}_{2}$. Am efectuat, de asemenea, imunofenotipare a măduvei osoase, care a pus în evidență un aspect imunofenotipic de leucemie limfoblastică acută cu celule pre-B. Examenul citogenetic nu a evidențiat mutaţii genetice. Examenul din lichidul cefalorahidian a fost negativ. Pe baza tuturor celor menționate mai sus, am stabilit diagnosticul de leucemie acută limfoblastică cu celule pre-B, risc standard. Am iniţiat chimioterapie conform protocolului ALL-IC-BFM 2009, cu evoluție favorabilă, biopsia medulară din ziua 15 şi 33 indicând absenţa limfoblaştilor. Până în prezent, pacientul este în remisie completă, primind tratament citostatic de menținere. Toleranța la chimioterapie a fost bună, fără a înegistra efecte adverse majore.

\section{DISCUTुII}

Leucemia acută limfoblastică este unul dintre cele mai frecvente tipuri de cancer care apare la copii, dar, în ciuda incidenței sale crescute, mai mult de 90\% dintre copiii diagnosticați cu LAL ajung în remisie, având o şansă de supraviețuire promițătoare (12). Pacientul nostru a prezentat, de asemenea, evoluție favorabilă după administrarea chimioterapiei standard, fiind în remisie completă. Tipul LAL cu origine în limfocitele B prezintă o frecvență de până la $85 \%$, iar subtipurile sale sunt definite conform stadiului de maturare limfocitar, cu toate că majoritatea provin din limfocite precursoare B, denumite LAL cu celule pre-B (7). În mod similar, în cazul nostru, imunofenotiparea a evidențiat un aspect de LAL cu celule pre-B. Printre altele, prognosticul LAL depinde foarte mult de prezența diferitelor anomalii cromozomale, care pot fi asociate fie cu un prognostic bun, fie mai puţin bun. De exemplu, hiperploidia $\mathrm{t}(12,21)$ este o anomalie cromozomală cu prognostic bun, în timp ce hiperploidia $t(9,22)$ şi leucemia cu rearanjamente mixte au fost documentate a avea prognostic prost (13). Din fericire, examenul genetic nu a evidențiat anomalii cromozomale în cazul prezentat mai sus, şi astfel am clasificat cazul ca având risc standard.

Triggerul declanşator al LAL nu este clar stabilit şi diferite ipoteze au fost propuse pentru a explica debutul acestei patologii. Anumite studii subliniază faptul că dezvoltarea LAL implică genopatii, ano- 
malii cromozomale predominant dobândite în timpul hematopoiezei fetale, care vor duce la o clonă preleucemică sublinică şi/sau modificări genetice secundare postnatale (14). Cu toate acestea, evenimentul exact care va determina clonele preleucemice să evolueze spre LAL rămâne neidentificat (9). Alte studii susțin ideea dezvoltării LAL din cauza unei lipse de mobilizare a sistemului imun ca rezultat la expunerea insuficientă la agenţi infecțioşi (15). În plus, după debut, LAL va afecta în mod sigur funcționarea sistemului imun din cauza producției în exces a limfocitelor imature, anormale, care nu îşi pot îndeplini funcția. Prin urmare, în majoritatea cazurilor, pacienții prezintă leucocitoză severă la debutul bolii, sugerând o posibilă LAL, ceea ce impune efectuarea unei biopsii medulare, care va stabili diagnosticul final.

Deşi este clar dovedit consensul că sindromul mielodisplazic poate precede leucemia acută limfoblastică, pre-LAL rămâne o entitate neclară, rară, cu o prevalență de 1,3-2,2\% la copiii diagnosticați cu LAL $(8,16,17)$. Simptomul inițial al pre-ALL este febra asociată cu pancitopenie evidențiată de HLG şi apare de obicei la copiii cu vârsta sub 10 ani, afectând mai ales fetele (18). Pe de o parte, similar datelor din literatură menționate anterior, vârsta pacientului nostru a fost de 2 ani, dar, pe de altă parte, el a fost de sex masculin. De asemenea, Villarreal-Martínez et al. au raportat 2 cazuri pediatrice de LAL, care au debutat ca anemie aplastică (9). Primul a descris un băiat de 5 ani, care s-a prezentat cu abces perianal, a cărui HLG a evidențiat o $\mathrm{Hb}$ de 5,0 g/dL, leucopenie şi trombocitopenie. În mod similar, cazul raportat de noi a descris un băiat, care a prezentat, de asemenea, abces perianal şi o $\mathrm{Hb}$ de $5,5 \mathrm{~g} / \mathrm{dL}$, uşoară leucopenie, dar un număr de trombocite în limite normale. Al doilea caz raportat de aceiaşi autori a făcut referire la un pacient, de sex masculin, în vârstă de 2 ani, cu un istoric de 2 săptămâni de infecție de tract respirator superior, scaun de culoare închisă, febră, care s-a prezentat cu o $\mathrm{Hb}$ de $1,5 \mathrm{~g} / \mathrm{dL}$, fiind în cele din urmă diagnosticat cu LAL, la fel ca şi primul caz descris de aceiaşi autori. Pacientul nostru, la aceeaşi vârstă ca şi cel din urmă caz descris de Villarreal-Martínez et al., a prezentat un istoric de 2 săptămâni de infectie de tract respirator. În concluzie, este foarte clar că pre-ALL este o entitate foarte rară care apare la copii şi adolescenți. $\mathrm{Cu}$ toate acestea, Liang et al. au raportat un caz al unei paciente, în vârstă de 50 de ani, cu pancitopenie tranzitorie, prezentând febră, tuse şi anemie, care a fost diagnosticat cu LAL la 3 săptămâni după tratamentul pancitopeniei (18). În mod similar, pacientul nostru a fost diagnosticat cu LAL după aproximativ 2 săptămâni de la externare. De asemenea, în cazul descris de Liang et al., parametrii de laborator au evidențiat anemie severă, neutropenie şi un număr normal de trombocite, similar cazului nostru. După cunoştințele noastre, acesta este a treilea caz de vârstă pediatrică raportat în literatură care a prezentat pancitopenie tranzitorie în calitate de condiție preleucemică, dar primul care a asociat pneumonie masivă înainte de debutul LAL.

Este bine documentat faptul că LAL la copii poate mima diferite patologii ortopedice, cum ar fi durerea osoasă, articulară sau musculoscheletală, ducând la întârzierea diagnosticului corect (19). Simptomele artritei septice au fost frecvent descrise în cazul copiilor cu LAL, mai ales cele de la nivelul genunchiului şi şoldului (19). În mod similar, pacientul nostru a prezentat afectare a articulației genuchiului drept, interpretată iniţial ca artrită septică, ulterior fiind definită ca afectare articulară în contextul LAL.

Neoplaziile reprezintă o adevărată povară la orice vârstă, dar mai ales la copii, astfel că diagnosticul şi tratamentul precoce sunt imperioase pentru a creşte rata de supraviețuire. Pancitopenia tranzitorie, din cauza rarității sale, maschează în cele mai multe cazuri diagnosticul de LAL, ducând la o întârziere a diagnosticului sau chiar conducând medicul spre un diagnostic greşit.

\section{CONCLUZII}

Monitorizarea clinică şi paraclinică a copiilor cu infectiii severe este obligatorie pentru a exclude alte patologii subiacente, precum neoplaziile sau imunodeficiențele. Prin urmare, monitorizarea corespunzătoare a acestor copii poate duce la diagnosticarea şi tratarea precoce a unor patologii mai severe îmbunătăţind prognosticul şi rata lor de supraviețuire. De asemenea, pancitopenia tranzitorie, deşi rară, trebuie luată în considerare în toate cazurile, iar pacientul trebuie să beneficieze de o monitorizare adecvată pe termen lung chiar şi după tratamentul acesteia. 